\title{
"He made me fall at the feet of a woman": Masculine Anxieties and Dysfunctional Romance in Tamil Cult Film Subramaniyapuram (2008)
}

\author{
Divya A \\ Assistant Professor in the Department of Humanities and Social Sciences in the Indian \\ Institute of Technology Madras. ORCID: oooo-ooo2-4516-6763. Email: divya@iitm.ac.in
}

\begin{abstract}
Tamil Cinema is "one of India's largest, most prolific and increasingly significant cinemas" (Velayutham 2008, pp.1-2). Madurai genre in Tamil films is popularly known as 3M films (Murder, Mayhem and Madurai) (Damodaran Gorringe 2017, p.9). Subramaniyapuram (Sasikumar, 2008) is a Madurai film that attained cult status in both the Indian states of Tamil Nadu and Kerala since its release in 2008. A collection of essays on Subramaniyapuram edited by anthropologist Anand Pandian was published in 2013, a rare honour to be bestowed on a Tamil film in recent times. Significantly, the film's problematic gender narrative-especially the entangled relation between the romantic plot and the masculine "plots"-is not the central subject of exploration of any of the essays in this edited collection, nor has it been discussed in depth in any critical discourse on the film so far. In this article, using Laura Mulvey's theoretical lens as a point of departure, I argue that the female identity is crucial to the narrative functioning of the various plots of Subramaniyapuram. The film's ultimate narrative desires, I illustrate, are in affirmation of masculine supremacy, hegemonic masculinity, and the women as femme fatales.
\end{abstract}

Keywords: Subramaniyapuram, Madurai, Tamil cinema, Masculinity, Gaze, Mulvey, Sasikumar, Romantic plot.

\section{Introduction}

The Tamil film industry within Indian Cinema is massive, rivaling "Hindi cinema in output, (arguably) in quality, and in fan devotion" (Nakassis \& Dean, 2007). "Tamil language cinema is more robust than any European national cinema has ever been" (Younger, 2009). Velayutham (2008) hails the "multi-million dollar industry" Tamil Cinema as "one of India's largest, most prolific and increasingly significant cinemas" (pp.1-2). Madurai genre films—set in and around the district of Madurai in the south of Tamil Nadu-has become synonymous with assertions of specific caste dominance, rural realism, and a New Tamil Wave in the industry (Leonard, 2015; Damodaran and Gorringe, 2017; Kailasam, 2017). Blockbuster films in the Madurai genre include Kaadhal (Balaji Sakthivel, 2004), Gilli (Dharani, 2004), Paruthiveeran (Ameer Sultan, 2007), Subramaniyapuram (Sasikumar, 2008), and Aadukalam (Vetrimaaran, 2011). This genre is popularly known as 3M films-(Murder, Mayhem and Madurai) (Damodaran \& Gorringe, 2017 p.10); the Southern region of Tamil Nadu, especially Madurai district, is associated with "primordial violence" (Krishnan, 2008, p.150). While the political reach and caste consolidation of Tamil films have often been the central topics of critical study, the role of masculinity in the construction of the cinematic imaginaries of Tamil films needs wider critical attention.

\footnotetext{
(C) AesthetixMS 2021. This Open Access article is published under a Creative Commons Attribution Non-Commercial 4.o International License (http://creativecommons.org/licenses/by-nc/4.o/), which permits non-commercial re-use, distribution, and reproduction in any medium, provided the original work is properly cited. For citation use the DOI. For commercial re-use, please contact editor@rupkatha.com.
} 
A Madurai film whose cult status has remained unchallenged since 2008 is Subramaniyapuram. The film was a runaway success in addition to being critically-acclaimed, becoming a landmark film in both the Indian states of Tamil Nadu and Kerala. Newspapers such as the Times of India (2018) continue to participate in the periodic act of commemoration of the film by reporting on the film's selling points. Malayalam and English translations of the film's screenplay have been published. ${ }^{i}$ A collection of essays on Subramaniyapuram (including the English translation of its screenplay) edited by anthropologist Anand Pandian- who also translated the film's script along with Kausalya Hart and Constantine V. Nakassis-was published in 2013, a rare honour to be bestowed on a Tamil film in recent times. Award-winning Hindi director Anurag Kashyap's admiration for Subramaniyapuram is well-documented. Kashyap declared in 2012 that he was inspired "to go back to my roots" by the "the Madurai Triumvirate, Bala, Ameer Sultan \& M. Sasikumar" (Pandian, 2013, p.x). Kashyap's critically acclaimed film series Gangs of Wasseypur were inspired by Subramaniyapuram (Hindustan Times 2018).

Subramaniyapuram's popular and critical appeal largely rested apparently on the film's realism. Social media comments (with hashtags "Subramaniyapuram" and "12yearsofSubramaniyapuram" continuing to celebrate the film, its screenings, and inspirations), YouTube videos by viewers, newspaper reports, and research articles celebrate the realism of the film. Abishek Rajaa (2018), whose YouTube video titled "Subramaniyapuram, a very special cult classic", containing an "analysis" that had been liked by thousands of viewers, states that the thud with which the murdered Azhagar falls to the ground was much remarked upon at the time of the film's release as symptomatic of unsentimental realism.

Subramaniyapuram was considered to offer the audience "fresh new perspective that dripped with raw emotion" (Aiyappan, 2018). Constantine V. Nakassis (2013) states that Subramaniyapuram was "filled with the quintessential hallmarks of classical realist cinema" (p. 218), and that according to the director Sasikumar it is the film's "realism" that made it a "hit" ( p. 217). The key question asked by some women in Dindigul of the director on his thanks tour in the aftermath of the film's success was how could Ganja Karuppu "take money to do that"the decision to play the role of the traitor in the film (Nakassis, 2013, p.222). Holding up the character of Kasi-played by the actor Ganja Karuppu who was abused for his "villainy" in the real world, not the screen world-Nakassis (2013) argues for the "fundamental openness of cinema to the world" and that the "afterlife of Subramaniyapuram, how it clings to the body of Ganja Karuppu, [is] a sign of disregard of the fictitious lines that separate the screen from the not-screen" (p. 222-223). What is significant to note in the discourse of realism in Subramaniyapuram, as discussed by a range of critics across academic and popular domains, is its strong and sole investment in the masculine narratives.

While masculinity and its manifestations in the various "plots" are examined for its realistic impact on the audience, the dysfunctional romance plot and the nature and function of feminine identity are largely marginal to the critical and popular discourse of Subramaniyapuram. Nakassis (2013) in his article on realism in the edited book on the film raises a set of puzzling queries "(Did the heroine get killed in the end or not? Were critical scenes edited out?)", and comments (such as "the nature of, and tensions between, male friendship and romantic love") that are not pursued for a detailed critical examination (p.217). For Pandian, there is a wonder "with Thulasi, or with Azhagar's mother, why it seems so difficult for these young men to understand what lies within their hearts" (Pandian, 2013, p. 215). Pandian (2013) sharply defines the character of the film as "the angry pulse of masculine aggression" (p.215), but the nature of the relation between masculine "aggression" and women in the film does not get discussed at any length. The problematic gender narrative-especially the ultimate fate of the heroine and the entangled relation between the romantic plot and the masculine plots-is not the central subject of exploration of any of the essays in the edited collection by Pandian, 
nor has it been discussed in depth in any critical discourse on the film so far. In this paper I aim to discuss the skewed nature of its gender discourse. Though chauvinism is pointed out as a character flaw in the central male characters in Subramaniyapuram (Rajaa, 2018), it is implied as a passing comment, as well as a puzzle, as Pandian (2013) notes about the nature of masculinity in the film. While the ultimate fate of the heroine becomes a minor curiosity, the tantalizing possibility of her horrible death is dangled in front of the eyes of the viewers through the circulation of a disturbing chase in a trailer video of the film in 2008. This scene, and a related image pertaining to her potential fate - depicted in the cover photo of Subramaniyapuram edited by Pandian - of the trapped Thulasi, are not included in the film.

I also argue that the film's masculine narratives are structured in such a complex manner that the performance of masculinity is enacted with the intention of reinforcing existing feminine stereotypes, and they perform the ideological work of disciplining the female gaze. I show how the masculine narratives - structured around the gangsters, the politicians, the romantic male, and the avenging men-are constructed for domination of the female identity. Laura Mulvey (1989) places women - the sexual object embodying the notion of "to-be-lookedat-ness" - at the centre of visual pleasure:

"As the spectator identifies with the main male protagonist, he projects his look on to that of his like, his screen surrogate, so that the power of the male protagonist as he controls events coincides with the active power of the erotic look, both giving a satisfying sense of omnipotence. Male movie star's glamourous characteristics are thus not those of the erotic object of the gaze, but those of the more perfect, more complete, more powerful ideal ego conceived in the original moment of recognition in front of the mirror" (p.20).

Mulvey's theory states that the male on the screen and off the screen are united in the "omnipotence" of their gaze of the female as a sexual object. The male is in control of the gaze because he is in command of the action of the narrative.

"Most Tamil movies are hero-centric. Female characters are meant to support the male protagonists and are presented as pleasurable objects for the heterosexual male gaze" (Karupiah et al., 2020).

While the female becomes an object, the male forever seems to remain an ideal, a "powerful ideal ego". Originating with Freud, the term is used to connote narcissism and an "idealized image of oneself as omnipotent" (Oxford Reference, 2020). For Lacan, ideal ego is the "ideal of perfection that the ego strives to emulate" (Felluga, 2011). For the male audience, the heroes on the screen are the images of perfection that they strive of emulate. The heroes on the screen on the other hand hope to reflect and reconstruct ideal images of masculinity in the theatre of the world in which the gaze of the female simultaneously endorses and is disciplined by the masculine narratives. Therefore, even when these heroes fail the women are held responsible as the feminine approval and esteem are supposed to be the main springs of masculine identity construction and agency. Geetanjali Gangoli (2007, p.95) writes powerfully of the internalization of regressive gender roles and the culturally restrictive codes of conduct by the Indian women, which strengthen masculine hegemony. I ultimately argue that the female gaze is a passive consumer and participant in male narratives and thus becomes paradoxically the vital narrative function that sets in motion and complicates the trajectories of romance and political intrigue in Subramaniyapuram. Further, the concept of "Hegemonic Masculinity" as understood by Demetriou (2001) continues to be a useful context to read the film under consideration in my article; he "identifies two forms of hegemony, internal and external. "External hegemony" refers to the institutionalization of men's dominance over women; "internal hegemony" refers to the social ascendancy of one group of men over all other men" (qtd.in Connell \& Messerschmidt, 2005, p.844). 


\section{Femme Fatales and the Negotiation of Masculinity}

The film narrates a murky tale set in Madurai in the nineteen eighties. A group of youngstersAzhagar, Paraman, Kasi, Doppa and Dumkan-are encouraged to kill the district political head of the ruling party by Kanagu, who is the younger brother of an ex-councillor called Somu, so that the latter can step into the position. Azhagar and Paraman seek to murder Kanagu once they realize that their loyalty has been betrayed since he refuses to bail them out of jail. The friends get bail with the assistance of Ravi, their jail inmate, who eventually uses them to murder his enemy, and thus furthers the young men's life of crime. Azhagar's romance with Thulasi, the daughter of Somu, is kept a secret from her family until near the close of the film when the unexpected discovery of the relationship leads the family to use her as a bait to draw Azhagar to an isolated place so that he can be killed. Kasi turns over Paraman to the murderers arranged by the politician's family for money, and Kasi is finally murdered decades later when he is released from jail by Dumkan.

The New Tamil Wave films are structured around notions of "real life", "Dark, gritty tales", "shoestring budget", "unknown cast, and a raft of fledgling technicians" (Pandian, 2018, p.ix). Despite the fact that this New Wave, neo-noir and Madurai genre film is made up of hitherto unknown central characters, concepts of heroic and hegemonic masculinity are loudly endorsed in Subramaniyapuram through the way in which the male navigates his life as a friend, gangster, avenger, and lover. Vasugi Kailasam (2017) points out that "in neo noir...male anxiety emerges as a projection onto the figure of the Tamil woman" (pp.30-33).

Subramaniyapuram most spectacularly offers the subversive space to its women, by subtly and largely pointing the finger of blame at them as the guiding rationale behind men's irrational and criminal behaviour in society. The film manifests its anxiety about modernity by exploring it through its gender narrative, by etching its women as always already treacherous figures in the grand narrative of masculinity.

Sasikumar insists that politics is the keynote of his film. He points to the pervasive nature of politics and how it seeps into private domains, including the domestic. The director states that the film:

may talk about love and friendship, and the betrayals involved in both, but primarily the film is about politics, the way politics pervades and shapes local neighborhoods and even domestic space. In that sense it is a political film that had to be faithful to a period of transition in Madurai. That was when this kind of rowdyism, criminality, and gangsterism emerged as a major feature of political life....I was keen to show how household relationships are tied to manoeuvres in the power equations with the political parties. (Krishnan, 2013, pp.246-247)

The lives of Azhagar, Paraman, and his friends are shaped by the machinations of the local political figure and his brothers. Though it has become a critical commonplace to realize that the personal is political and vice versa, it is significant to understand the nature of the dynamics between the personal relationships and the political machinations in this film. Sasikumar points out that the familial relations are impacted by strategizing for power positions within the political party. Somu's wife's satisfaction with her domesticity-and therefore the peace within their home for his extended family-depends on Somu's securing the district chief's position. Somu's wife berates her husband for failing to be in a position of power and compares him to a woman who hides when faced with failure, and thus prompts her husband into hitting her to reassert his masculine authority. This family squabble over Somu's political setback is the immediate trigger for Kanagu's request, in the very next scene at a lodge, to Azhagar and his friends to murder the politician Palanisamy. During the meeting Kanagu woefully informs the young men that: 
Even the women in our house don't respect us anymore. Fine. How can they respect us? Anybody who's used to a bit of power and authority, can they give it all up, just like that? They can't, can they? (Pandian, 2013, pp. 109)

Somu's wife had apparently enjoyed her "powerful" place in society when her husband had been a member of the municipal council, and had been looking forward to the pride and power that comes with the tag of the wife of the district party chief once her husband is successful in climbing ranks of the party. The reference to "anybody" in Kanagu's clever rhetoric alludes to women who enjoy power through their husbands; his analysis of the situation explains the women's "disrespect" towards the failed men. He strategically speaks of the power-hungry nature of the women, and elides the desires of the men in fighting for positions of power. The intensifier "even" suggests the assault to masculinity that the men in his family suffer from "lower"/ "weaker" beings such as the women, and he exploits that common bond of masculine identity with the youngsters to seek their solidarity and empathy for the plight of his family's men. Thus, a closer scrutiny reveals the gendered nature of the relation between the political and the personal. More specifically, there is a sub-conscious consensus among the men about the common goal of establishing/asserting their supremacy over the women in Subramaniyapuram. Therefore, in the discourse of the conflict between two social groups of men, what emerges crucially are these two cultural narratives in this cinematic discourse: a) the supremacy of the male over the female ultimately is unchallenged, and b) it is the female who "dictates" the power drive/agency of the male.

\section{Disciplining the Romantic Plot}

Romantic love signifies the individuals' decision to control their own sexuality and therefore the nature of their future family unit. In films, "The family remains sacrosanct in major narratives", with "devotion" towards it signifying "a highly-regarded virtue" (Pugsley \& Pongiyannan, 2020), and Sangita Gopal states that the family "abrogates to itself a law that is beyond its jurisdiction to the family as a transmitter of values" (qtd in Pugsley \& Pongiyannan, 2020). Subramaniyapuram illustrates major differences between Thulasi and Azhagar in terms of their familial and social markers. Thulasi is a member of an extended family that stays under the same roof, and all its adult males work overtly towards strengthening the political power of the family through Somu's rise. The heroine possesses two important characteristics-a higher class position and a strong extended family. The superior status of Thulasi is indicated by her spacious and imposing house in the town, and its protective nature is indicated by the grilled gate and windows. Her social dominance over Azhagar is also indicated through her frequent presence in the upper balcony that looks down on the makeshift audio shop that is almost a second home to Azhagar and his friends.

The enviable attributes of the romantic hero in Subramaniyapuram are minimal. He is economically and socially an embodiment of the dispossessed. He is jobless, and neither does he exhibit a desire to seek one, despite repeated exhortations from his widowed mother, and even from Thulasi. Moreover, except for his mother and an unseen uncle who supports the family in terms of its sustenance Azhagar has no blood relative. There is no space in Azhagar's small house for socialization, and therefore in the film his domestic space is primarily represented as a narrow corridor outside the house where his mother and friends sit drinking tea. Thus, there is a striking difference between Azhagar and Thulasi in terms of class and family as Azhagar is barely embedded in a strong and thriving kinship network.

In the absence of admirable class and kinship markers for Azhagar, masculinity and its attributes become central to the romantic narrative. Velayutham (2008) writes that: "Tamil masculinity is epitomized by the wearing of a moustache, physical prowess, authority, sexual virility and the capacity to control women" (p.8). Azhagar represents masculinity through his physical prowess in beating up, and later by murdering, his opponents. Though sexual virility is 
not overtly displayed, it is hinted at in his flirtatious gaze towards Thulasi. He successfully controls his mother, who is unable to change or resist his attitudes, and Thulasi's loyalty too except at the very end. In fact, after he commits the first murder, he seeks Thulasi's confirmation of their relationship, and is overjoyed when she reiterates her constancy towards him. The scene illustrates his power over Thulasi who is at pains to establish her allegiance towards Azhagar. He verbally abuses her family, and rebukes her too in the fear that she would snap ties with him. She however does not reject her lover because that would put her purity symbolically at stake. C.S. Lakshmi (2008) writes that at home "The woman becomes the guarantor of authenticity by occupying an unsullied and 'pure' space" (p.23). For Thulasi to retain the label of the good woman, it is only appropriate that she accepts the nature of her lover's masculinity despite his criminal behaviour. With her endorsement of his violent masculinity, Azhagar thrives in his path of murder. The female is essential to authenticate the identity of the male; she is the approving audience for his masculine narrative. In fact, Thulasi is the mirror that reinforces the narcissism of the aggressive and violent male.

What possibly prevents Thulasi from snapping ties with Azhagar is the Tamil cultural code of feminine propriety in which chastity is the guiding principle. The majority of Thulasi's glances at Azhagar are aslant, from the corner of her eyes; her surreptitiousness suggesting that she is not fully disregarding the regulation of modest demeanour. "Honor in films (as in social life), is...gendered; women protect their chastity whilst men protect their masculinity, respect and their women" (Damodaran \& Gorringe, 2019, p.6). Her loyal response to Azhagar's berating talk that rhetorically questions Thulasi's fidelity towards him, even after his act of murder, springs from her desire to protect the tenets of female chastity. To withdraw her love for the male whom she has chosen to give her heart away would put her chaste nature under threat. Therefore, even when Azhagar states that he did not meet her "to explain whether I'm a good guy or a bad guy", but that he would like to know whether she is still in love with him, Thulasi responds by showing him her only romantic memorabilia, a clipping of a newspaper report about the recent political murder that also contains a photograph of the arrested Azhagar and Paraman in a roughed-up appearance. The newspaper clipping becomes an emblematic proof of Thulasi's love for Azhagar; the paper clip becomes a kind of Bible on which she takes an oath that she would continue to love him despite public censure and scandal for his crime. Her parting words "Don't ever doubt me ever again" (Pandian, 2013, pp. 162) - though ironic in retrospect-is intended to assert her fidelity in love towards him. The uncompromisingly aggressive masculinity of Azhagar command the specific response of approval from the feminine - and she performs as culturally directed and dictated in the theatre of men in Subramaniyapuram.

\section{Divided Loyalties}

Yet, ironically, the treachery of the female as the direct cause of the destruction of the male is the ultimate cautionary message of the film. In the final statements of the film Paraman bemoans Azhagar's stubbornness in not ending his romantic association with Thulasi. Azhagar is butchered by Kanagu's henchmen because Thulasi successfully brings him out of hiding for an isolated rendezvous. Azhagar does not carry weapons on him when he is with Thulasi because he blindly believes that nothing can go wrong for him in her presence. He considers her as a protective charm. Therefore, when he realizes that Thulasi has betrayed him to his uncle's gangsters, Azhagar, the man who thrived on preserving his masculine prowess, does not even attempt to protect his own life by fighting back his attackers. The female not just fails to protect her lover; she is directly responsible for his violent death.

In Subramaniyapuram in the battle between the ideology of romance and that of the family the latter wins, with the heroine ultimately forced to harness her strength for the survival of her family. Thus, the family successfully closes its ranks against a dangerous outsider. As the revenge spirals into a heady violence, Thulasi is begged by her family to save its lineage. She is 
"He made me fall at the feet of a woman": Masculine Anxieties and Dysfunctional Romance in

Tamil Cult Film Subramaniyapuram (2008)

asked to be the "family deity" of their "lineage" by giving up her association with Azhagar, who is a threat to the lives of all the male members in her family (Pandian, 2013, p.191). As Azhagar is being butchered by his henchmen, Kanagu appreciates Thulasi for saving the family's honour and for reiterating her kinship with her family. Thus, her solidarity as well as her responsibility towards her family—by protecting it against its destroyers—is clearly established.

There is a powerful cultural dialectic at play in relation to the function of the young woman in Subramaniyapuram. Through the embedding of the romantic heroine in the landscape of small-town political maneuverings and the trajectory of the rise of gangsters, the film subtly seeks to illustrate her ultimate duties towards her patrilineal masculine authorities. In fact, to elicit maximum acting potential from the hero and the heroine of the film, the betrayal of Thulasi was kept a secret until very close to the shooting of the scene in the film (Pandian, 2013, p. 213). Pandian writes of the heroine who played Thulasi in the film: "Swathi went crying to her room," Sasi said. She called him [the director] on the phone from there, wailing, "I should've died instead of betraying him like this"' (Pandian, 2013, p. 213). The reaction of the actress who played the role of Thulasi towards the negative culmination of the romance of Thulasi and Azhagar reflects her loyalty towards the romantic narrative and not the familial. This "valorization of romantic love" (Nakassis \& Dean, 2007, p.79) on the part of Swathi, the actress, is a reaction that does not take into consideration the powerful politics that underlines the role of the romantic heroine in Subramaniyapuram. C.S.Lakshmi(2008) writes that:

"Since the family is seen as the hub of Tamil culture in Tamil Cinema, unusual women characters have to be constantly tamed and brought into the fold of the family or they have to be humiliated or eliminated, sometimes rather violently" (p.27).

Subramaniyapuram illustrates its central family unit craftily bringing Thulasi back into its fold while eradicating Azhagar. In the clash between the masculinity represented by Somu and his brothers, and the identity exuded by Azhagar and Paraman, the hegemonic masculinity of the former triumphs through its class, family and political power nexus. Significantly, the values of Somu's family are not allowed to be subverted either by modernity that is represented by women's education in the film or by the masculinity of the underprivileged.

Kailsam(2017) points out that:

"angst has always been characterized as exclusively male and a strong patriarchal culture backed by Dravidian Tamil nationalism has validated the anxiety over the place of Tamil identity and culture as exclusively male" (p.33).

This film is troubled by the impinging of modernity that seems to break the barriers of class and culture. The youngsters definitely seem to bond beyond caste differences-Kasi is definitely not the same caste as the rest of his friends. Azhagar and Paraman are unmarked by caste specificity. Azhagar is unfazed by his lower-class status when romancing the upper-class Thulasi. Thulasi, and her friends, are comfortable with the idea of romantic marriage. In fact, Thulasi is ready to elope with Azhagar, and thus reject the conventional route to matrimony that is preferred by her family. In light of these trajectories of modernity which override caste and class, evincing a kind of equality and individuality, the film's narrative sets up oppositional forces. Women are strategically used to resolve the culture complications that arise from the clashing of the forces of masculinity and modernity. Thulasi plays both the roles of the romantic heroine and the femme fatale, and thus becomes a totemic female identity that responds to, and navigates, the feudal and the individual desires. Male anxiety perceives women's nature and identity as both attractive and dangerous. The famous song in the film "Kangal Irandal" (lyrics by Thamarai) reflects the problematic duality of the woman who seems to be fatally attractive to the hero. The song - in tandem with the romantic ideology of several Tamil songs - reiterates the notion that the romantic female has not only the power to draw the male to her, but also to decimate the hero: 


\begin{abstract}
"With just two eyes,
With your two eyes,

You bound me up and drew me to you.
\end{abstract}

\author{
Wasn't that enough, that \\ With a little smile, a cunning smile, \\ You finished me off and buried me?" (Pandian, 2013, p.73)
}

The male sings of being tied up, finished off, and buried by the devasting beauty of the courting female, ideas that are simultaneously part of the exaggerated language of romantic courtship, which glorify in a negative figure of speech the powerful properties of the romantic female. Yet, it is also disturbingly prophetic in Subramaniyapuram as the final fatal fate of Azhagar is brought about by the agency of Thulasi. The Tamil word "Kalla" used to define her smile refers to notions of "cunning", "conniving", or "thieving", one that she exploits to "bury him"/hide him from the world. The smile literally becomes the chasm in which he is killed off. Though death is a common metaphor used to capture the throes of a lover's pain or rapture (usually of a sexual nature), the gendered identity of female as a combination of pain and pleasure, dangerous yet seductive, underscores the primary impetus of the film that pits the masculine against the feminine in order to resolve the complications of an embroiled feudal culture that is gradually being eroded by forces of modernity. Kailsam (2017) writes that the new wave cinema is characterized by anxiety about "the rightful place of the Tamil woman" (p.33). Subramaniyapuram partakes in this narrative by exploiting the cultural and narrative function of the role of woman in establishing the hegemonic narrative of masculinity, minus the modernity represented by romance. In terms of narrative resolution, romance is manipulated to resolve the political and gangster plots of the film. It is also pertinent to note that the song "kadhal siluvaiyil", meaning the "the cross of love" (lyrics by song writer Yugabharathi), poetically offers Azhagar's subtle "confession" that he committed the crime of murder for the sake of his beloved. Thulasi's love seems to have crucified Azhagar.

\title{
5. Spectacular iteration of male supremacy
}

The major character of Subramaniyapuram can ultimately be identified as the pursuit of reiteration of masculine authority. Manifestations of this quest are exhibited in this film through its deeply interconnected political plot, the gangster plot, and the romantic plot. The political plot of Somu and his brothers cannot be seen as supreme, with its impact simply spilling into domestic, friendship, and romance trajectories in a simple downward trickle-down effect. The relation between the political and the personal needs to be perceived as a rhizomatic pattern, with the masculine struggle for assertion of dominance across socio-political institutions and interpersonal relationships. Ultimately, the film sacrifices the romantic plot in order to illustrate the supremacy of the masculine authority of the family of Somu, who at the end of the film is the district chief of a political party. In the final fight for power between masculinities, Azhagar finally loses Thulasi and his life; Somu's family regains their woman; and thus, the battle between the young men and the older politically powerful, economically secure, and personally crafty men ends with the latter emerging more successfully. Somu wins the "respect" of his wife, thus asserting his masculine hegemony, and retrieves his daughter from the clutches of an unwanted male.

Masculine anxiety and its eagerness to reiterate dominance in the face of the feminine identity underline the logic of the film. The gangster plot begins in earnest when Azhagar desperately and urgently seeks revenge for the humiliating experience of having to fall at the feet of a woman in her home so that she would give refuge and not kick him out where a gang 
is roaming the streets to kill him. His fear of death becomes secondary to his degradation in the presence of woman. He cries to Paraman:

"he made me beg for my life from some woman...(hitting his head) Ayyo, ayyo, ayyo! He made me beg for my life from a woman, da...He made me fall at the feet of a woman!" (Pandian, 2013, p.180).

He seeks to recover his masculinity that was apparently emasculated by his falling at the feet of a female. Azhagar is eager to avenge his mortification by murdering the men who forced him into such a helpless position, and his exhortation for revenge sends him and his friends into a spiral of blood craze. Throughout his character trajectory, Azhagar refuses to compromise on his masculine aggression- except when Thulasi turns him over to his enemies - a violent personality that is used for identity iteration of the male.

Subramaniyapuram explores various manifestations of masculinities. Azhagar, Paraman, Somu and Kanagu and the others exhibit various facets of masculine identities. Paraman for instance does not hestitate to throw a brick at Thulasi when she makes a face at him when bumping into him on the streets of the town. Though the scene is intended for comic effect, with Azhagar grinning at Thulasi and preventing Paraman from attacking her, it is evident that Paraman's attitude towards young women ranges from annoyance and cynicism to anger. Sreeram Gopalkrishnan (2019) writes that film noir has

"a stylized narrative often using a voice-over exploring the psychology of the male protagonist amidst the presence of a femme fatale in the background of pessimism and depression" (p.3).

After Paraman avenges Azhagar's death, Paraman's "mind voice" comments on his friend's romance with Thulasi. It becomes an innovative voice-over that explains to the audience the dissident nature of romance and its fatal repercussions for the male. Later, he tells Kasi in a "philosophical" tone what can be perceived as the moral of the film: "I had told him repeatedly not to associate with a female. But he never listened to me. He got cheated". ii Paraman uses the derogatory Tamil word "Pottachi" to refer to a woman. Paraman in this scene does not specify the woman by referring to the name Thulasi, or by the usage of the determiner "that" before the term "Pottachi". He thus generalizes "the disturbing role" played by Thulasi when he comments on the death of his friend, and constructs the dangerous stereotype of women as threats to the life of men.

For Subramaniyapuram, a female is in essence a femme fatale. All its various plots play out in relation to the masculine construction of the ideological gaze-implicit or explicit-of the female as an identity that is to be overpowered by various means. The figure of the courting female is exploited to resolve the complications in the political narrative of Somu and the romantic plot of Azhagar. The revenge narrative of the gangsters takes a strange afterlife with regard to the role of the female. There is a surreal revenge plot of Paraman targeting Thulasi which does not exist within the film. A trailer video from 2008 shows Paraman chasing Thulasi down a narrow lane wielding a knife in hand, and Thulasi bangs on a closed door seeking in vain to escape (Subramaniyapuram Movie Trailer New, 2008). She turns around suddenly indifferent to her fate and sits down on a slab on the ground. Paraman's hunt is a scene of revenge for Thulasi's betrayal of Azhagar, a narrative that is not included in the film. Nakassis (2013, p.217) ruminates about this scene as referring to a murder that could either have happened within the world of Subramaniyapuram or as a scene that could have been edited out of the film. The former is a real possibility in terms of Paraman's character trajectory, a natural culmination of his unhesitating intention to assault Thulasi with a brick early on in the narrative. The knifewielding Paraman's chase of Thulasi continues to haunt and inhabit the critical domain of the film as the cover picture of the edited book on Subramaniyapuram by Anand Pandian. The cultural currency of the deleted scene - with the vulnerable Thulasi and a dagger-holding 
Paraman crouching on a dead end - offers violence as the masculine heritage of Subramaniyapuram. Living or dead, the female is essential to the reiteration of masculinity in the cinematic imaginary of this Madurai film, as the eponymous hero Kuttipuli (played by Sasikumar, and directed by M. Muthiah, 2013) aptly informs a friend: "Only if a woman wills it, you and I are masculine".

\section{Notes}

iSasikumar states that 'Subramaniapuram's script book was released in Malayalam by their leading magazine "Mathrubhumi"...[it] also featured me on their cover page and carried a 13-page long interview feature. We were also given the 'Best Pathbreaking Film' at an awards event in Kerala.' (Kaushik 2018).

ii This remark by Paraman in the film is translated into English by me.

\section{References}

Aiyappan, A. (2018).10 years of Subramaniyapuram: It is a personal milestone and a target as well, says director Sasikumar. The Indian Express. https://indianexpress.com/article/entertainment/tamil/ten-years-of-subramaniyapuramsasikumar-anurag-kashyap-5245318/

Anurag Kashyap reveals Gang of Wasseypur was inspired by Tamil movie Subramaniapuram. (2018, July 5). Hindustan Times. https://www.hindustantimes.com/regional-movies/anurag-kashyapreveals-gang-of-wasseypur-was-inspired-by-tamil-movie-subramaniapuram/storyS612FuhJ5Wr8S5pUkBOugP.html

Connell, R.W \& Messerschmidt, J.W. (2005). Hegemonic Masculinity: Rethinking the Concept. Gender and Society, 19(6), 829-859. Sage Publications, Stable URL: https://www.jstor.org/stable/27640853

Damodaran, K., \& Gorringe, H. (2017). Madurai Formula Films: Caste Pride and Politics in Tamil Cinema. South Asia Multidisciplinary Academic Journal. https://doi.org/10.40oo/samaj.4359

Dickey, S. (1993). The Politics of Adulation: Cinema and the Production of Politicians in South India. The Journal of Asian Studies, 52(2),pp. 340-372. doi:10.2307/2059651

Felluga, (2011). "Terms used by Psychoanalysis." Introductory Guide to Critical Theory. Purdue U. Retrived from https://cla.purdue.edu/academic/english/theory/psychoanalysis/psychterms.html

Gangoli, G. (2007). Indian feminisms: Law, patriarchies and violence in India. Aldershot, England, Burlington, VT. : Ashgate.

Gopalkrishnan, S. (2019). Marginalised in the New Wave Tamil Film: Subaltern Aspirations in three films by Bala, Kumararaja and Mysskin. Rupkatha Journal on Interdisciplinary Studies in Humanities, 11(2), pp. 1-9. https://dx.doi.org/10.21659/rupkatha.v11n3.03

Kailasam,V. (2017). Framing the neo-noir in contemporary Tamil Cinema: Masculinity and modernity in Tamil Nadu. South Asian Popular Culture,15(1), pp- 23-39,DOI: 10.108o/14746689.2017.1351788

Karupiah, P., Pathmanathan, S., \& Nikku, B. R. (2020). Perception of sexual violence in Tamil movies by Malaysian Indian viewers. Feminist Media Studies, 1-16. DOI: 10.1080/14680777.2020.1850501

Kaushik, L. M. (2018, June 28). 10 years of Subramaniapuram: Director Sasikumar Goes Down Memory Lane. Film Companion. https://www.filmcompanion.in/features/tamil-features/10-years-ofsubramaniapuram-director-sasikumar-goes-down-memory-lane/

Krishnan, R. (2008). 'Imaginary geographies: the makings of 'South' in contemporary Tamil cinema'. In Selvaraj Velayutham(Eds), Tamil Cinema, The cultural politics of India's other film industry (pp.139-153). London and New York : Routledge.

Krishnan,R. (2013). 'The Locality if the Real Hero of the Film'. A conversation with M.Sasikumar. Subramaniapuram. Edited by Anand Pandian. Chennai: Blaft Publications. 
Lakshmi C.S, (2008). 'A good woman, a very good woman: Tamil cinema's women'. Tamil Cinema. In Selvaraj Velayutham(Eds), Tamil Cinema, The cultural politics of India's other film industry (pp.16-28) . London and New York : Routledge.

Leonard, D. (2015). Spectacle spaces: Production of caste in recent Tamil films. South Asian Popular Culture, 13(2), pp. 155-173. https://doi.org/10.1080/14746689.2015.1088499

Mulvey, L. (1989).Visual and other pleasures. Basinstoke Macmillan.

Nakassis V. C. (2013) "Realism, On and Off the Screen." In Anand Pandian, ed. Subramaniyapuram: The Tamil Film in English Translation. Chennai: Blaft Publications, pp. 217-23.

Nakassis, C., \& Dean, M. (2007). Desire, Youth, and Realism in Tamil Cinema. Journal of Linguistic Anthropology,17(1), 77-104. www.jstor.org/stable/43104133

Oxford Reference, (2020). Ideal Ego. https://www.oxfordreference.com/view/10.1093/oi/authority.20110803095956512

Pandian, A.(2013). 'Introduction'. Subramaniyapuram. Chennai: Blaft Publications.

Pandian, A. (2013).Subramaniapuram : Screenplay. Translated by Kausalya Hart, Constantine V. Nakassis, and Anand Pandian. Chennai: Blaft Publications, pp. 1-205.

Pugsley, Peter C. \&Pongiyannan, Dhamu (2020). Progressive moralities: introducing new discourses of gender and sexuality in 1990s Tamil film songs. New Review of Film and Television Studies, 18(2), 151-170, DOI: 10.1080/17400309.2020.1732178

Rajaa, A. (2018). Subramaniyapuram, a very special cult classic [Video]. YouTube. https://www.youtube.com/watch?v=YjeEdWSY2zw\&list=PL6Q5qXdBejKlzy41SJGFPgZiTicsLhf Mo

Subramaniapuram Movie Trailer New. [Chiruzyou] [Video]. YouTube. https://www.youtube.com/watch?v=eySm8aSxI_8

Velayuthum, S. (Ed.). (2008). Tamil Cinema: The Cultural Politics of India's Other Film Industry. London and New York: Routledge.

Younger, P. (2009). Review . Tamil Cinema: The Cultural Politics of India's Other Film Industry. Ed. S. Velayutham(2009). New York\& Routledge. https://www.yumpu.com/en/document/read/20606931/tamil-cinema-the-cultural-politics-ofindias-other-

10 Years of "Subramaniapuram": Anurag Kashyap praises Sasikumar's classic - The Times of India(2018, July 4). https://timesofindia.indiatimes.com/entertainment/tamil/movies/news/10-years-ofsubramaniapuram-anurag-kashyap-praises-sasikumars-classic/articleshow/64852319.cms

\footnotetext{
Author Bio

Divya A is an Assistant Professor in the Department of Humanities and Social Sciences in the Indian Institute of Technology Madras. She has taught courses such as Regional Indian Literatures in Translation, the Rise of the Novel, and Short Story Classics. Her literary and cultural research interests are in the fields of gender, domesticity, spatiality, contemporary regional Indian literature, films, colonial Indian literature, and Shakespeare. She has published articles on Charles Dickens, Elizabeth Gaskell, Wilkie Collins, and the Pre-Raphaelites. Her international conference presentations have focused on colonial visuality, Victorian Indian writers, and towns. Her current research project is on regional Indian writings. Divya completed her Master of Studies in Early Modern English Literature in the University of Oxford, the U.K., and her PhD in Nineteenth- Century English Fiction in Nanyang Technological University (NTU), Singapore. She was a Postdoctoral Teaching Assistant at Singapore University of Technology and Design, Singapore.
} 